\title{
Legal Resilience in an Era of Grey Zone Conflicts and Hybrid Threats
}

\author{
Aurel Sari \\ University of Exeter
}

\begin{abstract}
The international system has entered a period of increased competition, accompanied by a steady retreat from multilateralism and international institutions. The purpose of this article is to assess the legal implications of these developments from the perspective of three concepts that have risen to prominence in recent years: lawfare, hybrid warfare and grey zone conflict. In doing so, the article makes three arguments. The instrumental use of international law for strategic purposes forms an integral feature of international relations and should not be mistaken, as realists are prone to do, for the irrelevance of law in international affairs. Although the notions of lawfare, hybrid warfare and grey zone conflict all contribute towards a better understanding of the ways in which international law is employed for strategic ends in the current security environment, neither offers a sufficient framework for analysis and policy action. Instead, the challenges posed to status quo powers by the revisionist instrumentalization of international law are best countered by adopting a legal resilience perspective and an operational mindset.
\end{abstract}

\section{Introduction}

Throughout most of the world, Canada is renowned for its contribution to the cause of multilateralism, international institutions and the progressive development of international law. Canadians often pride themselves on their country's long-standing commitment to the international rule of law (Fitzgerald et al 2018). It therefore seems out of character for Canada to stand accused of a blatant violation of its international obligations. Yet this is the charge levelled against it by the Russian Federation.

On 17 October 2018, the Cannabis Act entered into force in Canada. ${ }^{1}$ The Act created a regulatory framework that permits the controlled production, distribution, sale and possession of cannabis. By legalizing the recreational use of the drug, the Act put Canada on a collision course with three international drug control treaties (Habibi and Hoffman 2018). ${ }^{2}$ As the International

1. Cannabis Act (SC 2018, c 16).

2. Single Convention on Narcotic Drugs, 30 March 1961, 18 UST 1407, 520 UNTS 151; Convention on 
Narcotics Control Board, the body charged with overseeing the implementation of the agreements, has pointed out, the Cannabis Act is incompatible with Canada's international commitments. ${ }^{3}$ Russia's accusations against Ottawa are therefore not unfounded, it seems. Nevertheless, their tone is curious. In its statements on the matter, Russia has complained of Canadian 'high-handedness' and repeatedly emphasized the deliberate and fundamental nature of its violation of the applicable rules. ${ }^{4}$ Never shy of hyperbole, Russian officials have also accused the Canadian Government of consciously destroying the international drug control regime, promoting selective compliance with international agreements, failing to perform its obligations in good faith and belying its selfprofessed support for a rules-based world order. Notwithstanding Canada's failure to comply with its obligations, these accusations ring hollow. Their mocking tenor does little to conceal their primary objective, which is to paint a picture of Canadian duplicity and disdain for international rules that stands in stark contrast with the Russian Federation's record of strict compliance and heartfelt concern for the fate of the international legal order.

The passing of the Cannabis Act and Russia's attempts to turn it into a propaganda coup present a sorry spectacle. They are just one sign among many which suggest that the rules-based international order is in trouble. The last decade has seen the return of a multipolar international system marked by the resurgence of realpolitik and increased competition between the great powers (see Mazarr et al 2018; Porter 2019). By annexing Crimea, Russia has violated one of the core principles of international law (Grant 2015; Geiß 2015; Bering 2017), the rule against the acquisition of another State's territory through force (Korman 1996). ${ }^{5}$ China is asserting its interests more vigorously in the international arena, claiming parts of the South China Seas (Dupuy and Dupuy 2013; Gao and Jia 2013) ${ }^{6}$ and rejecting the award rendered against it in this matter by

Psychotropic Substances, 21 February 1971, 32 UST 543, 1019 UNTS 175; United Nations Convention Against Illicit Traffic in Narcotic Drugs and Psychotropic Substances, 20 December 1988, KAV 2361, 1582 UNTS 95.

3. Statement by the International Narcotics Control Board on the entry into force of Bill C-45 legalising cannabis for non-medical purposes in Canada, 17 October 2018, UNIS/NAR/1362.

4. Ministry of Foreign Affairs, Comment by the Information and Press Department on Canada's steps to legalise cannabis for recreational use, 22 June 2018, 1199-22-06-2018; Statement of the Permanent Representative of the Russian Federation to the International Organizations in Vienna Ambassador Mikhail Ulyanov at the 2nd intersessional CND meeting, Vienna, 25 June 2018, 28 June 2018, 1240-28-06-2018; Statement of the Permanent Representative of the Russian Federation to the International Organizations in Vienna Mr Mikhail Ulyanov at the 5 th intersessional meeting of the Commission on Narcotic Drugs, Vienna, November 7, 2018, 8 November 2018, 2127-08-11-2018.

5. GA Res 2625 (XXV), Declaration on Principles of International Law concerning Friendly Relations and Cooperation among States in accordance with the Charter of the United Nations, 122-123 (24 October 1970).

6. See, for example, Note Verbale CML/8/2011 from the Permanent Mission of the People's Republic of China 
the Permanent Court of Arbitration. ${ }^{7}$ Western powers too are prepared to disregard international rules at times, as they did by striking Syrian regime targets in response to chemical attacks on civilians in April 2018 (Goldsmith and Hathaway 2018; but see Dunlap 2018).

These incidents feed into broader concerns about the future direction of the international system. Recent withdrawals from international institutions and agreements, such as Burundi's departure from the International Criminal Court (Ssenyonjo 2018; Alter, Gathii and Helfer 2016) ${ }^{8}$ and the US renunciation of the Iran nuclear agreement and other international instruments (Talmon 2019), ${ }^{9}$ suggest that support for multilateralism is waning (see Cohen 2018). International law and institutions are being side-lined and appear increasingly impotent. Judge James Crawford $(2018,1)$ of the International Court of Justice has captured the prevailing mood by observing that nowadays international law is invoked in 'an increasingly antagonistic way', whilst at other times it is 'apparently or even transparently ignored.'

The present article places these developments within the context of the current debates over lawfare and the legal dimension of hybrid warfare and grey zone conflicts, with the aim of moving these debates onto new, more fruitful ground. The paper advances three core arguments. First, it suggests that the instrumentalization of law and legal processes is an integral feature of the international system, one from which a certain creed of realism draws the mistaken conclusion that a rules-based international order cannot possibly exist. Second, it argues that the notions of lawfare, hybrid warfare and grey zone conflict all contribute towards a better understanding of the role that international law plays in the contemporary strategic environment, but that neither of these three concepts offers an adequate framework for analysis and policy action. Finally, it suggests that the challenges posed by the instrumentalization of international law are best countered by adopting a legal resilience perspective and fostering an operational mindset.

\section{The tragedy of international law}

To some, the dire state of international law and multilateralism merely confirms that the notion of

to the UN Secretary-General, 14 April 2011; Note Verbale CML/17/2009 from the Permanent Mission of the People's Republic of China to the UN Secretary-General, 7 May 2009.

7. The South China Sea Arbitration (Phil v China) (Perm Ct Arb 2016). For the Chinese position, see Ministry of Foreign Affairs of China (2016).

8. UN Secretary-General, Depositary Notification, C.N.805.2016.TREATIES-XVIII.10, 28 October 2016.

9. Remarks by President Trump on the Joint Comprehensive Plan of Action, 8 May 2018,

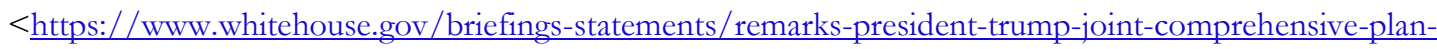
action/>, accessed 20 December 2019. 
a rules-based international order is a delusion. In the aftermath of the Cold War, John Mearsheimer (1994) warned against the 'false promise' of international institutions as a means for promoting peace and stability, a view echoed in the latest US National Security Strategy. ${ }^{10}$ More recently, Patrick Porter (2016; see also Porter 2018) has argued that a rules-based international order is unattainable. The world is a 'tragic place' where great powers break the rules at their discretion if it serves their interests. To believe that order in international relations can be based on strict rules is to engage in wishful thinking.

Realist scholars are right to pour scorn on the legalist belief that formal rules and institutions can supplant power politics. But legalism so defined offers a thoroughly romanticized account of the role of law in international affairs, one that is little more than a caricature. Law is a function of political society, as EH Carr (1939, 227-231) argued years ago. This means that law's authority derives, ultimately, from politics and is sustained by a concrete social order. But it also means that law serves a distinct social need. Law provides society with predictability. It affords a sense of 'regularity and continuity' without which political life would not be possible (ibid, 232; see also Luhmann 2004, 142-172). Porter (2016) suggests that a workable international order must be forged not by lawyers, but by canny diplomats relying on 'compromise, adjustment, mutual concessions and a continually negotiated universe, backed by deterrence and material strength.' Yet it is difficult to see how such compromise, adjustment, concessions, negotiations and even deterrence (see Schelling 2008, 49-55) could be sustained without formal rules and institutionsor lawyers, for that matter.

Classic realists were more perceptive in this regard. Discussing the decentralized nature of international law in his Politics among Nations, Hans Morgenthau $(1948,214)$ made the following observation:

Governments... are always anxious to shake off the restraining influence which international law might have upon their international policies, to use international law instead for the promotion of their national interests, and to evade legal obligations which might be harmful to them. They have used the imprecision of international law as a ready-made tool for furthering their ends. They have done so by advancing unsupported claims to legal rights and by distorting the meaning of generally recognized rules of international law.

This passage does not paint a flattering picture of international law, but it depicts its operation in more accurate terms than the cliché of legalism. In 2014, Russia did not simply invade and annex

10. The White House, The National Security Strategy of the United States of America (December 2017). The Strategy paints a picture of continuous competition between States and a failure of international institutions to restrain and integrate revisionist powers, such as China. 
Crimea with a passing reference to the Melian Dialogue, ${ }^{11}$ but offered an elaborate legal argument to justify its actions (Borgen 2015; Ambrosio 2016). According to President Putin, in the absence of a legitimate executive authority in Ukraine, Russia was compelled to intervene to protect the people of Crimea and to create the conditions in which they could exercise their right of selfdetermination, ostensibly in line with the bilateral agreements governing the presence of Russian forces on the Crimean Peninsula. ${ }^{12}$ The use of such legal rhetoric for strategic ends has a long tradition. On 17 September 1939, the Soviet Union justified its invasion of Poland by arguing that the Polish State and Government had ceased to exist, that Soviet-Polish treaties therefore had lost their validity and that Russian military action was necessary to protect the life and property of the population of Western Ukraine and Western White Russia. ${ }^{13}$

Sceptics will object that the use of international legal arguments for the purposes of territorial aggrandizement hardly amounts to a ringing endorsement of a rules-based international order. But this misses the point. As Josef Kunz $(1945,549)$ once quipped, most international lawyers are comfortable working with two international laws: one for their own nation and one for their enemies. The rules, processes and institutions of international law facilitate cooperation between international actors in pursuit of their goals and values, but at the same time they also enable conflict by sustaining disagreement and competition. International law constrains as well as enables both friends and foes. Taking this insight to its logical conclusion, Monika Hakimi (2017) has recently argued that fostering cooperation and conflict are in fact symbiotic functions of international law (see also Hurd 2017). To annex Crimea, Moscow relied on well-established international instruments. It first recognized the 'Republic of Crimea' as a sovereign and independent State $^{14}$ and then entered into an international agreement with that 'Republic' to

11. Thucydides (2009), 5.84-5.111. The Melian Dialogue is regarded as a classic illustration of the necessities of power, famous for making the point that 'The strong do what they can: the weak suffer what they must' (ibid, 5.89). See Wassermann (1947).

12. Address by the President of the Russian Federation, 18 March 2014,

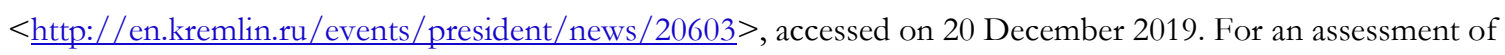
these claims, see Olson (2014).

13. The Ambassador in the Soviet Union (Steinhardt) to the Secretary of State, Moscow, 17 September 1939, in United States Department of State (1956), 428-429, 428-429. On Soviet efforts to justify the invasion of Poland, see Plokhy (2011).

14. Decree of the President of the Russian Federation No 147, 'On the recognition of the Republic of Crimea', 17 March 2014, < http://publication.pravo.gov.ru/Document/View/0001201403180002> (in Russian), accessed on 20 December 2019. 
incorporate its territory into the Russian Federation. ${ }^{15}$ In response, the member States of the European Union utilized Article 215 of the Treaty on the Functioning of the European Union ${ }^{16}$ to adopt restrictive measures against Russia with the declared aim of increasing the costs of its infringement of the territorial integrity, sovereignty and independence of Ukraine. ${ }^{17}$ Realists who see in the annexation of Crimea merely a violation of the prohibition to use force, and thus the irrelevance of law in the face of realpolitik, overlook the fact that international law and power interact in more subtle ways. ${ }^{18}$ Law is an instrument of power politics, a framework for countermeasures and a vocabulary for contesting legitimacy all at once.

Yet herein lies the tragedy of international law. Seen from a classic positivist perspective, international law, like any legal system, is instrumental in nature. Its purpose is to serve other ends: predictability, justice, security, the good life. However, since those ends are contested, international law itself is contestable and open to instrumentalization in the service of conflicting objectives and interests. ${ }^{19}$ There is a constant tension between those seeking to preserve the status quo embodied in the international system and those hoping to overthrow it (Morgenthau 1929, 75-78; Carr 1939, 230). The politicization of international law therefore is inevitable. All questions of international law are political to a greater or lesser extent (Morgenthau 1929, 69-70; Lauterpacht 1933, 155). Nonetheless, international law must constantly reassert its distinct logic and formalist modus operandi to avoid collapsing into politics (see Luhmann 2004, 76-141), otherwise it would no longer be capable of performing a distinctly legal function in the society it is meant to serve. ${ }^{20}$ If international law became mere policy, it would lose the predictability and normativity that sets it apart from

15. Agreement between the Russian Federation and the Republic of Crimea on the Accession of the Republic of Crimea to the Russian Federation and the Formation of New Federal Constituent Entities, 18 March 2014, <http://publication.pravo.gov.ru/Document/View/0001201403180024> (in Russian), accessed on 20 December 2019.

16. Consolidated Version of the Treaty on the Functioning of the European Union, 13 December 2007, 2012 OJ (C 326) 1 (EU).

17. Council Regulation 833/2014 of 31 July 2014 concerning restrictive measures in view of Russia's actions destabilizing the situation in Ukraine, 2014 OJ (L 229) 1 (EU).

18. Ironically, in so doing they display a remarkable lack of realism about the operation of international law. See Brownlie (1982).

19. It is a mistake, therefore, to assume that a rules-based international order must necessarily be a pluralist and liberal one. See Simpson (2001).

20. In the South West Africa Cases, Second Phase (Liber v S Afr; Eth v S Afr), Judgment, 1966 ICJ Rep 6, ๆ 49 (July 18), the International Court of Justice put this point as follows: 'Law exists, it is said, to serve a social need; but precisely for that reason it can do so only through and within the limits of its own discipline. Otherwise, it is not a legal service that would be rendered.' 
other functional systems. "We cannot reduce it to politics without eliminating it as law", as Oscar Schachter $(1982,25)$ warned.

International law is thus caught in a dynamic where the instrumental use of rules forms a core feature of the system, yet where certain forms and manifestations of instrumentalization are deeply corrosive to the idea of a rules-based international order (generally, see Tamanaha 2006). For example, State recognition constitutes a legitimate means to give effect to the right of selfdetermination of peoples, as happened in the case of Ukraine following its declaration of independence on 24 August 1991 (Rich 1993, 40-42). By contrast, using State recognition as a means to carry out the forcible annexation of another State's territory, as Russia has done in relation to Crimea, undermines the rule of law (Shany 2014). In cases such as these, a judicial body or other expert audience may find it relatively straightforward to distinguish between valid and invalid legal claims, and thus between the use and abuse of the law, as measured against established methods of interpretation and the substantive values and standards of behaviour enshrined in the international legal order as it presently stands. In other situations the dividing line between the acceptable and abusive instrumentalization of international law may not be so clear even to an expert audience (see, for example, Morton 2002, 99-101) and it will be even less evident to the general public. Indeed, more often than not, States and other actors employ international legal arguments not in order to convince a body of experts, but as a vocabulary of political persuasion, as a language of political judgment and legitimacy (Kennedy 2006), aimed to win over a wider audience at home or abroad. In an age of fake news and information warfare, we should therefore not be surprised to find that the boundaries between formal legal argumentation and blatant propaganda, between at least tenable legal arguments and legal disinformation, have become more fluid. International law thus oscillates between political tribalism and principled arguments over the validity of legal claims.

\section{Making sense of the strategic environment}

None of these dilemmas are new, of course (for example, see Henkin 1979, 88-98, and Koskenniemi 1990, 2005 and 2009). However, they have gained renewed vigour as a result of the more competitive international environment, the progressive legalization of foreign affairs and the growing appetite for legal accountability in our societies (see Rowe 2016). They thus lie at the heart of what Judge Crawford has called the turn to a more antagonistic international law.

In recent years, three concepts have entered the scholarly and policy discourse in an attempt to explain and frame these developments: lawfare, hybrid warfare and grey zone conflict. All three concepts make a useful contribution to a better understanding of the role of international law as a 
medium of strategic competition, but they also suffer from certain shortcomings and analytical blind spots.

\section{Lawfare}

The notion of lawfare was introduced into mainstream legal discourse by Major General Charlie Dunlap (2001). In his initial writings, Dunlap described lawfare as a 'method of warfare where law is used as a means of realizing a military objective' (ibid, 4). The example that most readily comes to mind is the deliberate violation by an adversary of its legal obligations in the hope of obtaining an illicit advantage on the battlefield. The law of armed conflict prohibits using the presence or movement of civilians to render certain points or areas immune from military operations, in particular in an attempt to shield military objectives from attack or to shield, favour or impede military operations. ${ }^{21}$ However, the fact that an adversary employs human shields in violation of this prohibition does not relieve another belligerent from its duty to protect civilians. ${ }^{22} \mathrm{By}$ prioritizing the protection of civilians, the law thus affords unscrupulous adversaries with an asymmetric advantage: placing civilians near military objectives may shield the latter from attack, provided that the attacking party continues to abide by its own obligations.

In the eyes of most commentators, lawfare is firmly associated with acting in bad faith (see Horton 2010, 170; Luban 2010, 458-459). However, in later writings, Dunlap emphasized its essentially neutral character $(2008,146-148 ; 2010,122 ; 2011,315)$. If law is a means of warfare, then the question whether its use is beneficial or harmful depends entirely on who is employing it for what purpose and against whom. Law, therefore, does not differ much from a rifle: whether or not a rifle is a good thing depends in large measure on which end of the barrel one happens to stand. Understood in these terms, lawfare is an agnostic concept that simply describes the use or abuse of law as a means to achieving a military goal (Dunlap 2010,122). It follows that lawfare can be a force for good. For instance, it is not far-fetched to describe the establishment of the International Criminal Tribunal for the former Yugoslavia as an example of lawfare, bearing in mind that one of the aims pursued by the Security Council was to influence the behaviour of the warring parties in the absence of effective military means to do so (Reisman 1998, 46-49; see also

21. Protocol Additional to the Geneva Conventions of 12 August 1949, and Relating to the Protection of Victims of International Armed Conflicts, art 51(7), 8 June 1977, 1125 UNTS 3 (Additional Protocol I). See Henckaerts \& Doswald-Beck (2005), 337-340.

22. Additional Protocol I art 51(8). 
Kerr 2004, 12-40). ${ }^{23}$

Others have built on Dunlap's work to refine the concept further. Orde Kittrie $(2016,8)$ defines lawfare as the use of law to create the same or similar effects as those traditionally sought from conventional military action, provided the party using law in this manner is motivated by a desire to weaken or destroy an adversary. The addition of an intent requirement is designed to exclude from the definition actions that are not hostile in character and thereby distinguish it from ordinary, adversarial lawyering.

Despite such refinements, the concept suffers from several limitations (see also Voetelink 2017). The instrumental use of international law is not confined to war. States regularly employ law and legal arguments to pursue their interests outside the context of armed hostilities, for example as China does in the South China Seas. As traditionally understood, lawfare fails to capture the instrumentalization of law beyond armed conflict and for purposes other than strictly military gains. In fact, even during armed conflict, non-State actors such as Hamas and Hezbollah do not resort to lawfare and place civilians at risk solely or even primarily in order to achieve a direct operational advantage. Rather, the benefit they seek often lies in the information domain, where they can exploit the increased rates of civilian suffering caused by their own failure to comply with the law to delegitimize their opponent (see Gemunder Center for Defense and Strategy 2018, especially 28-35; see also Blank 2017). The traditional concept also says little about the standards against which lawfare should be assessed. For example, what criteria should be applied to prioritize different instances of lawfare and to distinguish them from ordinary legal business? If lawfare truly is a neutral concept, how should law-abiding nations know where the dividing line between the legitimate use of law and its impermissible abuse lies (see Noone 2010, 83-85)? In the absence of general agreement on this question, lawfare is open to the charge that it is simply a label used to discredit perfectly routine legal claims by tarnishing them with the brush of illegitimacy (Hughes 2016; Irani 2017). The concept is also clouded by national experiences. In the UK, for example, lawfare seems indelibly, but unhelpfully, associated with narrow concerns over human rights litigation and its impact on military effectiveness (see Tugendhat and Croft 2013, 35).

\section{Hybrid warfare}

The notion of hybrid warfare originally emerged in the context of debates over the changing

23. SC Res 827, preamble (25 May 1993). See also UN SCOR, 48th Sess, 3217th mtg, 12 (France), 19 (UK), 21 (Hungary), 22-23 (New Zealand), 24-25 (Japan), 27 (Morocco) and 32 (Pakistan), UN Doc S/PV.3217 (25 May 1993). 
character of war and the associated question of future force structures and force modernization (Mattis and Hoffman 2005; see Tenenbaum 2015). One of the earliest proponents of the term is Frank Hoffman (2007; 2009). With adversaries increasingly deploying an integrated mix of conventional capabilities and irregular tactics in the same battlespace, Hoffman argued that distinct modes of warfighting, acts of terrorism and criminality were converging to produce a hybrid form of war. Following Russia's annexation of Crimea, the concept gained wider popularity and entered the Western strategic lexicon. In the process, it acquired a looser meaning to refer to the combined use of military and non-military, conventional and unconventional, overt and covert means of exercising influence (Fridman 2018). This conceptual drift has not escaped criticism. In the eyes of many commentators, a lose understanding of hybrid warfare is little more than a shorthand for geostrategic competition across multiple domains or a euphemism for Russian aggression that offers few, if any, useful insights (see Charap 2015; Monaghan 2015; Renz 2016). Responding to these criticism, other approaches define hybrid warfare as being aimed at exploiting the societal vulnerabilities of a targeted nation, including its political institutions, decision-making processes and critical infrastructure (see Multinational Capability Development Campaign 2019, 13). Understood in this way, hybrid warfare is more readily characterised as a method employed by revisionist actors.

Hybrid warfare is not a legal term of art and its conceptual fluidity has made it difficult to assess its legal implications (see O'Connell 2015; Wittes 2015). However, both NATO and the EU have associated certain legal challenges with the notion. ${ }^{24}$ Hybrid adversaries are said to deploy law and legal arguments in an effort to gain an operational or strategic advantage. They do so in several ways. They exploit the lack of legal interoperability and consensus among Western nations. They generate and exploit legal ambiguity. They also circumvent legal boundaries and thresholds to avoid triggering the applicability of mutual assistance commitments, such as Article 5 of the North Atlantic Treaty. ${ }^{25}$ In addition, it has become practically an article of faith that the classic distinction between war and peace is fading away as a consequence of the hybridization of warfare. For example, at their Brussels summit held in July 2018, NATO leaders took note of the increasing

24. In particular, see Supreme Allied Commander, Europe and Supreme Allied Commander, Transformation, BiSC Input to a New NATO Capstone Concept for the Military Contribution to Countering Hybrid Threats, 25 August 2010; Headquarters, Supreme Allied Commander Transformation, Assessing Emerging Security Challenges in the Globalised Environment: The Countering Hybrid Threats (CHT) Experiment, Final Experiment Report (FER), 29 September 2011; European External Action Service, Food-for-Thought Paper 'Countering Hybrid Threats', Council Doc 8887/15, 13 May 2015; European Commission, Joint Framework on Countering Hybrid Threats: A European Union Response, JOIN(2016) 18 final, 6 April 2016.

25. 4 April 1949, 63 Stat 2241, 34 UNTS 244. 
challenges posed by States and non-State actors 'who use hybrid activities that aim to create ambiguity and blur the lines between peace, crisis, and conflict. ${ }^{26}$

The narrow understanding of hybrid warfare, as initially proposed by Hoffman, describes a form of operational art and is therefore closely linked to the conduct of open hostilities. It shares this feature with Dunlap's definition of lawfare. In fact, lawfare has been identified as a specific hybrid warfare technique (Muñoz Mosquera and Bachmann 2016). The narrow understanding of hybrid warfare draws attention to the multimodal character of contemporary conflicts. This in turn highlights certain legal difficulties, such as the scope of application of the law of armed conflict and its interaction with other legal regimes. However, such a narrow perspective runs into the same objection as the classic definition of lawfare. Adversaries utilize hybrid tactics, including lawfare, not just in the shadow of impending armed conflict or during actual hostilities, but also in situations where there is no immediate prospect of war. The attempted murder of Sergei Skripal with a chemical nerve agent in the city of Salisbury on 4 March 2018 offers an example. ${ }^{27}$ This is why many commentators and organizations such as the European Union prefer to use the term hybrid threats instead. But that notion suffers from its own shortcomings: its inherent vagueness and sheer breadth undermines its utility as a framework for analysis.

One way out of this conceptual morass is to contextualize. According to the European Centre of Excellence for Countering Hybrid Threats, hybrid threats involve the systematic targeting of the political, social, economic, military and other vulnerabilities of Western nations by their strategic competitors and adversaries. ${ }^{28}$ Whether or not this definition should be read as a symptom of Western existential angst, as some have suggested (Mälksoo 2018), it does have the advantage of narrowing down the discussion to a set of empirically observable hostile tactics. These include plausible deniability, interference not reaching the level of prohibited intervention, acting through proxies, information operations and the use of force below the threshold of an armed attack. Rather helpfully, this also focuses attention on certain legal difficulties and areas of law, including the attribution of wrongful acts, the law of cyber operations, countermeasures, the rules governing the use of force and the law of armed conflict (see Cantwell 2017). This 'contextualized' hybrid

26. Brussels Summit Declaration, Issued by the Heads of State and Government participating in the meeting of the North Atlantic Council in Brussels, 11-12 July 2018, $<$ https://www.nato.int/cps/ic/natohq/official texts 156624.htm $>$, accessed on 20 December 2019.

27. Letter dated 13 March 2018 from the Chargé d'affaires a.i. of the Permanent Mission of the United Kingdom of Great Britain and Northern Ireland to the United Nations addressed to the President of the Security Council, UN Doc S/2018/218, 13 March 2018.

28. See <https://www.hybridcoe.fi/hybrid-threats/>, accessed on 20 December 2019. 
threat construct thus offers a more concrete typology of lawfare and a catalogue of more specific legal challenges to be addressed. Overall, however, the notion of hybrid warfare continues to fluctuate between too narrow and too broad a frame of mind.

\section{Grey zone conflict}

When a river enters the sea, the freshwater does not turn into seawater instantly. It tends to produce brackish water at first. War and peace may be polar opposites, but they too may converge in a mixed state. This realization that war and peace are continuous, rather than discrete, fields of human endeavour has given rise to the idea that they may blend into each other, producing a grey zone that is neither truly war nor truly peace (see Ruggie 1993, 28; Curtis 1994; Eide, Rosas and Meron 1995, 217). In recent years, strategic discourse has seized upon this image, above all in the United States, to spawn a range of related concepts, including the notion of grey zone threat and grey zone conflict.

A white paper published by the United States Special Forces Command $(2015,1)$ describes grey zone conflicts as 'competitive interactions among and within State and non-State actors that fall between the traditional war and peace duality'. This is a broad concept, but as the white paper emphasizes, some level of aggression is required to shift peacetime competition into the grey zone (ibid, 3). A report prepared by the International Security Advisory Board of the United States State Department $(2017,2)$ adopts a similar approach, arguing that the central characteristic of grey zone operations is 'that they involve the use of instruments beyond normal international interactions, yet short of overt military force'. Grey zone conflict may not be new or exceptional, but it is pathological, rather than normal. This represents one of the weak spots of the concept: wherein lies this pathological element that distinguishes grey zone operations from routine international rivalry? The International Security Advisory Board suggests that grey zone actors employ means that 'go beyond the forms of political and social action and military operations with which liberal democracies are familiar, to make deliberate use of instruments of violence, terrorism, and dissembling' (ibid). This approach is not unreasonable, but it relies heavily on perceptions of normality (see United States Special Forces Command 2015, 3).

Whereas the notion of hybrid warfare is preoccupied with the multimodal way in which adversaries operate, the grey zone concept focuses on the competitive space within which they conduct their activities. By definition, this space is marked by ambiguity about the nature of the conflict and the status of the parties, which in turn generates uncertainty about the applicable law (Mazarr 2015, 66; United States Special Forces Command 2015, 4). The Kerch Strait incident between Russia and Ukraine illustrates the point. On 25 November 2018, Russian coast guard 
patrol boats intercepted, fired upon and seized three Ukrainian navy vessels near the entrance of the Kerch Strait. Since Russia and Ukraine are engaged in an ongoing international armed conflict, the incident is governed not only by the general rules of international law, including the law of the sea, but also by the law of naval warfare, a point that is often overlooked (for example, see Gorenburg 2019). Even though Russia could have justified both the attack and the internment of the Ukrainian crew members with reference to the law of war (Kraska 2018), consistent with its efforts to deny its involvement in an armed conflict with Ukraine, it did not invoke its belligerent rights. In addition to generating legal uncertainty, grey zone conflicts also give rise to more specific legal challenges. Since operations in the grey zone for the most part involve the same tactics and techniques as those associated with hybrid warfare (International Security Advisory Board 2017, 2-4; Jackson 2017; Wirtz 2017, 107-110), they mostly raise identical legal questions (see Schmitt and Wall 2014; Nasu 2016, 260-269; Brooks 2018).

Implicit in much of the grey zone debate is a concern that a gap has opened up between the rules of international law, which are based on the traditional duality of war and peace, and the more amorphous character of contemporary warfare (see Leed 2015, 134-135). The law is often accused of lagging behind reality. The same concern animates much of the hybrid warfare debate, as reflected in its fixation on the dividing line between war and peace.

It is true that classic legal authorities have often denied that a middle ground exists between the state of war and the state of peace (Grotius 1625, Bk III, ch XXI, I.1). For most nineteenth century international lawyers, there existed but two categories of international intercourse: 'war and not war', as Lord Robertson put it in the case of Janson v Driefontein Consolidated Mines Ltd (see Neff 2005, 178-186). ${ }^{29}$ However, the reality of warfare never quite reflected this formalistic position. Even Clausewitz (1834, Bk VIII, ch 2) was forced to admit that the extreme and unrelenting application of violence, which he identified as the internal dynamic of war in an ideal sense, finds itself tempered in the real world by competing considerations. Limited objectives, lack of incentives and the fear of escalation breed military stagnation, 'half-wars' and a descent into the use of force as a mere threat (ibid, Bk VIII, ch 6). Legal practice has never quite lived up to the strict doctrinal distinction between war and peace either (Schwarzenberger 1943). Formal declarations of war were always the exception, rather than the rule (Maurice 1883; see also Greenwood 1987). Neither doctrine nor practice ever gave birth to a single definition of the state of war. In a valiant but ultimate unsuccessful attempt to define the concept, Clyde Eagleton (1932, 282) was forced to conclude that there was 'a great deal of uncertainty as to the meaning of war'.

29. Janson v Driefontein Consolidated Mines Ltd [1902] AC 484, 504 (House of Lords). 
The situation has not improved markedly in more recent times. Since 1945, States have found ways of employing force in circumstances not foreseen by the United Nations Charter. In doing so, they have adapted and recalibrated the Charter regime in several respects (see Franck 1970; Franck 2002).

Much of the grey zone debate fails to appreciate that in legal practice, the threshold between war and peace, and between their attendant regulatory frameworks, is therefore not as firm as the black letter of the law may suggest (see Hakimi 2018; see also Reisman 2013, 95-104). In important respects, the legal concept of war and peace are relative notions and the normative line that separates them is neither bright nor in fact is there a single line (see Grob 1949). All of this has important implications for the grey zone concept, since it is difficult to determine whether or not a particular competitive tactic or incident is pathological, and thus falls within the grey zone, based on normative considerations. It also means that grey zone conflicts not only generate legal ambiguity, but that legal grey zones generate conflict too.

The benefit of the grey zone construct thus lies mostly in the notion of greyness. Like the idea of a 'cold war' or 'hot peace', greyness denotes that the intensity of geopolitical confrontation lies somewhere between ordinary diplomacy and all-out war. Greyness also captures the murkiness associated with deniability, disinformation and other measures designed to deceive, confuse and subvert. By comparison, the image of a 'zone' is less helpful. Despite protests that the notion is not meant to replace the duality between war and peace with a tripartite model that distinguishes between war, the grey zone and peace (Joint Chief of Staff 2019, 3), in the eyes of most commentators, it seems to do exactly that. But this is misleading: the idea of a zone that is demarcated by peace at the lower end and by war at the top, and thus sandwiched between two boundaries, diverts attention away from the fact that hostile campaigns may exploit those very boundaries across different domains to achieve asymmetric coercive effects across the full spectrum of competition (see Adamsky 2018), rather than in any particular 'zone'.

\section{Facing up to the challenges}

From a legal perspective, the three concepts explored in the preceding section-lawfare, hybrid warfare and grey zone conflict-have proved themselves to be under-inclusive in some respects and over-inclusive in others. The legal community is thus confronted with a situation where policy and strategic discourse has adopted a language that does not translate well into legal doctrine and vice versa. By not engaging with the prevailing discourse on its own terms, lawyers open themselves up to censure for ignoring current strategic priorities, including concerns over the erosion of the rules-based international order (for example, Cabinet Office 2018, 6). Yet by adopting those terms 
uncritically, they run the risk of entangling themselves in concepts that may prove to be of limited benefit for legal analysis.

Nevertheless, certain insights may be identified. At the most general level, all three concepts underscore the instrumentalization of international law for strategic ends. Had Clausewitz been a lawyer, he might have observed that law is but a continuation of politics by other means. This is not to side with those realists who deny that international law is governed by its own, distinct logic. If they were right, the validity of international rules would depend on their political utility and not on legal criteria (see Peters 2018, 486). But then they would cease to be rules of law: law would be mere policy. Rather, it is to accept that international law is, by its very nature, politically contestable and open to instrumentalization for non-universal ends. As I have argued in greater detail elsewhere (Sari 2019,186-187), in the present context this instrumentalization takes on a particular form. In hybrid warfare and grey zone conflicts, adversaries rely on law and legal arguments predominantly in order to legitimize their own behaviour and maintain their own freedom of action and to delegitimize their opponents' behaviour and restrict their respective freedom of action. In addition, all three concepts draw attention to a set of tactics and techniques that adversaries tend to employ for these purposes. This combined catalogue of lawfare, hybrid and grey zone measures gives more concrete meaning to the instrumentalization of international law by enabling lawyers to identify specific legal questions, difficulties and vulnerabilities that demand their talents.

These are useful insights, as they increase situational awareness and contribute to a better understanding of the dynamics between international law and the pursuit of geopolitical objectives by revisionist actors. In addition, they also harbour important lessons about the nature of the legal challenges that status quo powers face.

\section{The national interest and the international rule of law}

The turn to a more antagonistic international legal system poses two types of challenges. By definition, the use of international law for geopolitical ends as part of a lawfare, hybrid or grey zone campaign affects the strategic position of the targeted State. The instrumental use of international law by adversaries thus presents a challenge, first of all, to the national interest of the on the receiving end of such a campaign. For methodological reasons, this is an important point to make. Understanding how adversaries utilize the law requires technical legal expertise. However, the strategic significance and impact of their actions is not something that can be assessed by legal criteria alone. These are questions of political judgment-informed by legal expertise, but not decided by it. A legal claim may be perfectly tenable under the law, but that does not prevent it 
from being pursued with malign or hostile intent. Moreover, whether a particular claim is legally tenable or abusive may be difficult to determine conclusively with reference to legal standards such as the principle of good faith (see Dill 2017, 125-128; see also Stephens 2011). Part of the answer depends on political criteria and thus, inevitably, on non-universal and non-formalistic considerations. If the exercise of political judgment in these matters cannot be avoided, it is more conducive to sound analysis, and intellectually more honest, to acknowledge this.

The hostile instrumentalization of international law also poses a challenge to the international rule of law. Many of the tactics employed — such as taking advantage of legal gaps and thresholds in bad faith, evading legal accountability, advancing untenable legal arguments, circumventing legal commitments or engaging in manifest breaches of the applicable rules—are incompatible with respect for the rule of law. The cynical evasion and manipulation of the law not only deepens the structural weaknesses of the international legal order, especially if the culprits are great powers, but it also leads other actors to question the wisdom of their own continued compliance. At a certain point, the accumulation of persistent and serious transgressions may threaten to undermine the integrity of the international legal system as such. Specifically, the instrumental use of the law risks politicizing international legal processes and discourse to the point where their ability to serve as an effective medium for resolving political disputes is compromised. The near complete schism between Western and Russian international lawyers in their assessment of Russia's annexation of Crimea-the former widely denouncing it as a grave violation of international law, the latter predominantly treating it as a lawful exercise of the right of self-determination-illustrates the danger (Roberts 2017, 231-240).

These two challenges are connected. When actors with a vested interest in the status quo are confronted with revisionist tactics, they face a choice. They may continue to comply with the rules that underpin the status quo and seek to reinforce them, but at the cost of abstaining from using the same illicit, though potentially effective, measures employed by their adversaries. Alternatively, they may attempt to beat revisionist powers at their own game and adopt their tactics, but at the expense of joining them in undermining respect for the rule of law. Law-abiding States must therefore navigate a precarious course: they cannot afford to counter lawfare, hybrid and grey zone challenges harmful to their national interests with identical means without chipping away at the international rule of law.

This dilemma between normative/compliant and non-normative/non-compliant counteraction manifests itself in many guises. For example, in the cyber domain, it is the United Kingdom's position that the principle of sovereignty does not prohibit one State from interfering with the computer networks of another State where such interference falls below the level 
prohibited by the principle of non-intervention (Wright 2018). On this view, cyber interference to manipulate the electoral system of another State is prohibited, but cyber operations to steal private data are not. There is no reason to doubt that this position reflects the genuinely held view of Her Majesty's Government about the current state of international law. However, it is also safe to assume that this view is informed by a pragmatic calculation of risk and reward: the threat that low-level cyber interference poses to the United Kingdom and the benefit the country may derive from conducting or threatening to conduct such cyber operations against its competitors. Although in taking this position the United Kingdom decided against relying on international rules to protect its cyber interests, and instead opted for a non-normative approach, its National Cyber Security Centre subsequently accused Russia of acting 'in flagrant violation of international law' for engaging in cyber interference precisely of the kind that the Government determined was not prohibited by international law. ${ }^{30}$ In the light of the Government's earlier position, this accusation lacks bite and smacks of double standards (see Biller and Schmitt 2018). The affair demonstrates that choosing brinkmanship over normative solutions, and vice versa, is not cost free.

The challenges posed by the instrumentalization of international law are complex and significant. They go to the heart of the relationship between law and power in international relations. It would be naïve, therefore, to believe that they can be resolved conclusively. Managing them and lessening their adverse impacts is a more realistic objective. Accordingly, status quo powers should aim to compete more effectively in the legal domain by defending the rule of law, deterring violations and rolling back revisionism. However, even this more modest goal requires a systematic and sustained effort. Such an effort, I suggest, should be based on two foundations.

\section{A legal resilience perspective}

The first step is to adopt a legal resilience perspective to guide policy at the strategic level. Resilience theory derives from multiple sources. One influential strand emerged in the field of ecology in the 1970s (Holling 1973). Over the years, resilience thinking has spread to other disciplines, including the social sciences and, to a lesser extent, law (see Humby 2014). Most of the resilience scholarship undertaken in the field of law is concerned with environmental law and related matters (see, for example, Demange 2012; Garmestani and Allen 2014; Benson 2015). By contrast, so far few attempts have been made to utilize the concept in the field of international

30. National Cyber Security Centre, Reckless campaign of cyber attacks by Russian military intelligence service exposed, 4 October 2018, <https://www.ncsc.gov.uk/news/reckless-campaign-cyber-attacks-russian-militaryintelligence-service-exposed $>$, accessed 7 January 2019. 
conflict and security law. This is a missed opportunity, as adopting a legal resilience perspective promises several benefits.

Legal resilience is concerned with the resistance of legal systems to change and their capacity to adapt in response to disturbances. In essence, the aim of legal resilience theory is to understand how legal systems cope with internal and external shocks. Legal scholarship has followed other disciplines in distinguishing between two forms of resilience (see Ruhl 2010, 1375-1378). Engineering resilience refers to the capacity of a system to suffer disturbances whilst retaining its ability to return to an earlier stable state. Picture a branch twisted by the wind: can it spring back into shape or will it break? Ecological resilience, by contrast, refers to the capacity of a system to absorb the effects of disturbances through adaptation, whilst still retaining its original function and other core characteristics. If the branch breaks, will the tree grow a new one? Both forms of resilience describe the ability of a system to retain its original functionality and identity in response to disturbance, but one focuses on static coping mechanisms (resistance and recovery) and the other on dynamic strategies (adaptation). This distinction translates well into the present context, given that the capacity of international law to endure in the face of persistent breaches and its ability to adapt to the changing international environment are key areas of concern. The literature also distinguishes between two different dimensions of legal resilience (ibid, 1382). The first dimension pertains to the role that law plays in rendering other social or functional systems, for instance the economy or critical infrastructure, more resilient. The second is concerned with the resilience of the law itself. This distinction resonates well with the twin challenges posed by the instrumentalization of international law. From a resilience perspective, we may ask, first, what contribution international (or domestic) law can make towards rendering societies more resilient against the threats posed by hybrid warfare and grey zone conflicts and, second, what measures are required to make the international legal order more resilient against violations and subversion of its norms, institutions and processes.

The first benefit of adopting a legal resilience perspective, therefore, is analytical. It shines a spotlight on the capacity of international law to cope with disturbances. This focuses attention on law's vulnerabilities and coping mechanisms. It also highlights that there is a difference between using international law in pursuit of societal resilience and increasing the resilience of the international legal order as such. The second benefit is for the formulation of policy. Resilience is not an absolute virtue. Few would wish to see the undesirable features of a social system become resilient to change. Sometimes law is an impediment to social progress, justice or peace and ought to change. However, for States that seek to safeguard their strategic position and the international rule of law against the hostile instrumentalization of international law, legal resilience is a value 
worth pursuing. A legal resilience perspective encourages States to make better use of international law to strengthen their national resilience and to bolster the capacity of international rules, institutions and processes to withstand their hostile instrumentalization by adversaries. Legal resilience is, essentially, a status quo strategy. Finally, adopting a legal resilience perspective should bring different expert communities and their notions of resilience (see Shea 2016; Brinkel 2017) closer together by underscoring that resilience has a legal dimension and international law a resilience aspect (see also Beichler et al 2014).

\section{An operational mindset}

If the use of international law for strategic ends teaches one lesson, it is that international law is a dynamic system composed not only of rules, but also of legal actors, decisions, institutions, claims and counter-claims (cf. Higgins 1994, 2). This dynamic nature of international law is often overlooked. Yet there can be little hope of successfully countering the hostile instrumentalization of international law unless the international legal order is treated as a sphere wherein actors engage in legal manoeuvres and counter-manoeuvres. This calls for the adoption of an operational mindset by legal practitioners and their clients. The point may be illustrated with reference to the role of legal advice in the armed forces.

First, in view of its nature as a web of rules, institutions and processes that shapes the conduct of military operations, law should be formally recognized in military doctrine and strategic thinking as a distinct environment within the overall operating environment. NATO defines the operating environment as 'a composite of the conditions, circumstances and influences that affect the employment of capabilities and bear on the decisions of the commander. ${ }^{31}$ Although the operating environment is understood to encompass all relevant physical and non-physical areas and factors, doctrine tends to focus on its political, military, economic, social, information and infrastructure (PMESII) dimensions, without specifically including law on this list. ${ }^{32}$ Instead, international law is treated outside this conceptual framework in its own right. ${ }^{33}$ Although this is to be welcomed to the extent that it acknowledges the distinct characteristics and special significance of the law, it nevertheless compartmentalizes legal affairs by isolating them, both conceptually and in practice, from other environments. Formally recognizing law as a dimension of the overall operating environment would remedy this.

\footnotetext{
31. NATO, Allied Joint Doctrine, AJP-01, February 2017 (edn 5, ver 1).

32. For example, NATO, Allied Joint Doctrine for the Conduct of Operations, \$S 0410-0414, AJP-3 (B), March 2011.

33. NATO, Allied Joint Doctrine, \S 1.13-1.19, AJP-01, February 2017 (edn 5, ver 1).
} 
Second, international law should be treated as a specific instrument and medium through which strategic and operational objectives may be pursued. Western military doctrine adopts a holistic and effects-based approach to targeting which is meant to consider 'all available actions and potential effects set against the operations objective'. ${ }^{34}$ Despite this supposedly full-spectrum approach, law is not recognized in express terms as a source of available actions and potential effects. Instead, legal considerations usually enter the targeting process in the guise of external constraints on targeting decisions and action. ${ }^{35}$ This perspective is too narrow. It fails to appreciate law's potential to achieve operational effects and the fact that operations sometimes pursue legal effects, as do freedom of navigation operations, for instance. Recognizing international law as an operating environment implies that it is a space in and through which effects may be achieved. Conceiving of law in these terms permits incorporating legal effects into the joint targeting process, which in turn provides a framework for undertaking information activities, fires and manoeuvres through legal means and to coordinate, synchronize and integrate these with other targeting activities - and to do so more consistently, effectively and subject to appropriate oversight and limitations.

Third, putting an operational mindset into practice requires sound doctrine, effective processes and adequate resources. At the heart of these requirements lies a recalibration of the way in which legal expertise is employed. Legal experts and advisors carry out a wide range of functions that include advising, litigating, negotiating and counselling. Their mandate may even involve contributing to policy planning and development (Hill 2016, 224). Whilst achieving legal effects may be implicit in most of these roles, it is seldom confirmed as an explicit responsibility. In the military context, for example, the legal advisor's principal duty is defined as assisting the commander in exploiting operational options (Ministry of Defence 2019, \ 5.1). Whereas legal advisors are expected to carry out their duties proactively, their job description fails to specifically charge them with the task of manoeuvring in the legal environment to achieve legal and operational effects. Both the law and legal expertise thus remain underutilized (see also Trachtman 2016, 281). To rectify this, it should be recognized that the role of legal experts is not simply to provide legal support to operations, but also to undertake legal operations (cf. Department of the Army 1991). This shift in perspective must be embedded in doctrine. It also requires robust procedures, guidelines and oversight. Inevitably, engaging in legal operations in a more deliberate fashion raises questions about the dividing line between the legitimate and illegitimate use of law. Enabling legal operations also requires closer collaboration with and support from other expert communities. In an

34. NATO, Allied Joint Doctrine for Joint Targeting, \0117, AJP-3.9, April 2016 (edn A, ver 1).

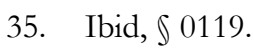


environment increasingly saturated with legal misinformation and fake legal news, particularly close attention must be paid to the interplay between legal expertise and strategic communications (generally, see Patrikarakos 2017; Singer and Brooking 2018).

\section{Conclusion}

Following the end of the Second World War, Great Britain peacefully relinquished control over vast stretches of its colonial territories and their 800 million inhabitants. Yet, as Thomas Franck (1983) noted, it was prepared to fight a war with Argentina over the Falkland Islands, an area of approximately 4,700 square miles and a population of less than 2,000. The difference, Franck suggests, lies in the legal principle at play: Britain deemed the Argentine invasion a violation of its territorial sovereignty. The Falklands War illustrates both the weakness of international law and its power to motivate and justify strategic action.

International law is torn between its function as an instrument for ordering international society in a principled manner and its inherent vulnerability to be diverted for partisan ends. In this paper, I have argued that it is this dynamic which sustains lawfare and the various other legal tactics and techniques that characterize hybrid warfare and grey zone conflicts. From a legal perspective, the key insight to be drawn from these concepts is the rampant instrumentalization of international law for strategic ends. That the international legal system is an arena of strategic competition is hardly news, but this point has far-reaching implications for theory and practice. A naïve legalism that puts its faith in rules divorced from considerations of power is headed towards disappointment or worse. However, a narrow realism that fails to appreciate the unique function of law both as an instrument of social order and as a platform for a principled critique of power, and thus as an object of strategic contestation, is headed towards the same fate. Turning to practice, if the world has taken a turn towards a more antagonistic international law, as seems to be the case, then law-abiding societies must come to realize that the hostile instrumentalization of international law may substantially undermine their interests and severely corrode the international legal order. Not only that, but they must also take concrete steps to counter these challenges. I have argued that such efforts should be based on two foundations: a legal resilience perspective and an operational mindset. Legal resilience highlights the contribution that international law can make to render societies more resilient against hybrid and grey zone threats and that the international rule of law itself must be strengthened to withstand the kind of subversion associated with these tactics. A legal resilience perspective thus offers diverse stakeholders a common framework for analysis and a shared set of objectives at the strategic level to guide them in countering the legal challenges arising in the current security environment. In addition, adopting an operational 
mindset provides legal practitioners and the clients they serve with an opportunity to recalibrate the way they use legal expertise. By treating law as an operating environment, they may develop more adequate capabilities to engage in legal operations and manoeuvre more deliberately through the legal space. 


\section{Notes on contributor}

Aurel Sari is an Associate Professor of Public International Law at the University of Exeter. He is the Director of the Exeter Centre for International Law, a Fellow of Supreme Headquarters Allied Powers Europe and a Fellow of the Allied Rapid Reaction Corps. His work focuses primarily on international conflict and security law and the rules relating to military operations. He has published widely on the law of armed conflict, status of forces agreements, peace support operations, international human rights law, the legal framework of European security and defence policy and, more recently, the legal aspects of hybrid threats. The present paper is written in a personal capacity, but has benefitted from discussions with colleagues in a range of fora, including the European Centre of Excellence for Countering Hybrid Threats, the International Institute for Strategic Studies, the Geneva Centre for Security Policy, the Judge Advocate General's Legal Center and School and the Center for Ethics and the Rule of Law at Pennsylvania Law School.

\section{References}

Adamsky, Dmitry "Dima” (2018) 'Strategic Stability and Cross-Domain Coercion: The Russian Approach to Information (Cyber) Warfare', in Rubin, Lawrence and Adam N. Stulberg (eds), The End of Strategic Stability? (Washington, DC: Georgetown University Press), 149173

Alter, Karen J, James T Gathii and Laurence R Helfer (2016) 'Backlash against International Courts in West, East and Southern Africa: Causes and Consequences', European Journal of International Law, 27:2, 293-328

Ambrosio, Thomas (2016) 'The Rhetoric of Irredentism: The Russian Federation's Perception Management Campaign and the Annexation of Crimea', Small W ars and Insurgencies, 27:3, 467-490

Beichler, Simone A, Sanin Hasibovic, Bart Jan Davidse and Sonja Deppisch (2014) 'The Role played by Social-Ecological Resilience as a Method of Integration in Interdisciplinary Research', Ecology and Society, 19:3 (4)

Benson, Melinda Harm (2015) 'Reconceptualizing Environmental Challenges: Is Resilience the New Narrative?', Journal of Environmental and Sustainability Law, 21, 99-128

Bering, Juergen (2017) 'The Prohibition of Annexation: Lessons from Crimea', New York University Journal of International Law and Politics, 49:3, 747-832

Biller, Jeffrey and Michael Schmitt (2018) 'Un-caging the Bear? A Case Study in Cyber Opinio Juris and Unintended Consequences', EJIL:Talk, <https://www.ejiltalk.org/un-caging-thebear-a-case-study-in-cyber-opinio-juris-and-unintended-consequences $/>$

Blank, Laurie R. (2017) 'Media Warfare, Propaganda, and the Law of War', in Gross, Michael L. and Tamar Meisels (eds), Soft War: The Ethics of Unarmed Conflict (Cambridge: Cambridge University Press), 88-103

Borgen, Christopher J. (2015) 'Law, Rhetoric, Strategy: Russia and Self-Determination before and after Crimea', International Law Studies, 91, 216-280

Brinkel, Theo (2017) 'The Resilient Mind-Set and Deterrence', in Ducheine, Paul A.L. and Frans P.B. Osinga (eds), Netherlands Annual Review of Military Studies (Winning Without Killing: The Strategic and Operational Utility of Non-Kinetic Capabilities in Crises) (The Hague: TMC Asser), 
$19-38$

Brooks, Rosa (2018) 'Rule of Law in the Gray Zone', Modern War Institute, $<$ https://mwi.usma.edu/rule-law-gray-zone/>

Brownlie, Ian (1982) 'The Reality and Efficacy of International Law', British Yearbook of International Law, 52:1, 1-8

Cabinet Office (2018) National Security Capability Review (London:

Cantwell, Douglas (2017) 'Hybrid Warfare: Aggression and Coercion in the Gray Zone', ASIL Insights, $\quad<$ https://www.asil.org/insights/volume/21/issue/14/hybrid-warfareaggression-and-coercion-gray-zone $>$

Carr, Edward Hallett (1939) The Twenty Years' Crisis 1919-1939 (London: Macmillan and Co Ltd)

Charap, Samuel (2015) 'The Ghost of Hybrid War', Survival, 57:6, 51-58

Clausewitz, Carl von (1834) Hinterlassene Werke des Generals Carl von Clausewitz, über Krieg und Kriegführung, Vol III (Berlin: Dümmler)

Cohen, Harlan Grant (2018) 'Multilateralism's Life Cycle', American Journal of International Law, $112: 1,47-66$

Crawford, James (2018) 'The Current Political Discourse Concerning International Law', Modern Law Review, 81:1, 1-22

Curtis, Willie (1994) 'Maneuvering in the Gray Zone: The Gap Between Traditional Peacekeeping and War Fighting, Peacemaking, Peace-Enforcement, and Post-Conflict Peace-Building', in Mokhtari, Fariborz L. (ed) Peacemaking, Peacekeeping, and Coalition Warfare: The Future Role of the United Nations (Washington, DC: National Defense University), 175-185

Demange, Lia Helena de Lima (2012) 'The Principle of Resilience', Pace Environmental Law Review, 30, 695-810

Department of the Army (1991) FM 27-100: Legal Operations (Washington, DC: Headquarters Department of the Army)

Dill, Janina (2017) 'Abuse of Law on the Twenty-First-Century Battlefield: A Typology of Lawfare', in Gross, Michael L. and Tamar Meisels (eds), Soft War: The Ethics of Unarmed Conflict (Cambridge: Cambridge University Press), 119-133

Dunlap, Charles (2001) Law and Military Interventions: Preserving Humanitarian Values in 21st Century Conflicts Carr Center for Human Rights)

Dunlap, Charles J, Jr (2008) 'Lawfare Today: A Perspective', Yale Journal of International Affairs, 3, 146-154

Dunlap, Charles J, Jr (2010) 'Does Lawfare Need an Apologia?', Case Western Reserve Journal of International Law, 43:1-2, 121-144

Dunlap, Charles J, Jr (2011) 'Lawfare Today... and Tomorrow', International Law Studies, 87, 315326

Dunlap, Charlie (2018) 'Yes, There Are Plausible Legal Rationales for the Syria Strikes', Lawfare, $<\underline{\text { https: / / www.lawfareblog.com/yes-there-are-plausible-legal-rationales-syria-strikes }>}$

Dupuy, Florian and Pierre-Marie Dupuy (2013) 'A Legal Analysis of China's Historic Rights Claim in the South China Sea', American Journal of International Law, 107:1, 124-141

Eagleton, Clyde (1932) 'The Attempt to Define War', International Conciliation, 15:291, 237-292

Eide, Asbjorn, Allan Rosas and Theodor Meron (1995) 'Combating Lawlessness in Gray Zone Conflicts Through Minimum Humanitarian Standards', American Journal of International Law, 89:1, 215-223

Fitzgerald, Oonagh E, Valerie Hughes, Mark Jewett and L Yves Fortier (2018) 'Conclusion', in Fitzgerald, Oonagh E, Valerie Hughes and Mark Jewett (eds), Reflections on Canada's Past, Present and Future in International Law (Montreal: McGill-Queen's University Press), 481484

Franck, Thomas M. (1970) 'Who Killed Article 2(4)? Or: Changing Norms Governing the Use of Force by States', American Journal of International Law, 64:4, 809-837

Franck, Thomas M. (1983) 'Dulce et Decorum Est: The Strategic Role of Legal Principles in the 
Falklands War', American Journal of International Law, 77:1, 109-124

Franck, Thomas M. (2002) Recourse to Force: State Action against Threats and Armed Attacks (Cambridge: Cambridge University Press)

Fridman, Ofer (2018) Russian "Hybrid Warfare": Resurgence and Politicization (Hurst)

Gao, Zhiguo and Bing Bing Jia (2013) 'The Nine-Dash Line in the South China Sea: History, Status, and Implications', American Journal of International Law, 107:1, 98-124

Garmestani, Ahjond S and Craig R Allen (eds) (2014) Social-Ecological Resilience and Law (New York: Columbia University Press)

Geiß, Robin (2015) 'Russia's Annexation of Crimea: The Mills of International Law Grind Slowly But They Do Grind', International Law Studies, 91, 425-449

Gemunder Center for Defense and Strategy (2018) Israel's Next Northern War: Operational and Legal Challenges (Washington, DC:

Goldsmith, Jack and Oona Hathaway (2018) 'Bad Legal Arguments for the Syria Airstrikes', Lawfare, < https://lawfareblog.com/bad-legal-arguments-syria-airstrikes $>$

Gorenburg, Dmitry (2019) The Kerch Strait Skirmish: A Law of the Sea Perspective (Helsinki:

Grant, Thomas D. (2015) Aggression against Ukraine: Territory, Responsibility, and International Law (Basingstoke: Palgrave Macmillan)

Greenwood, Christopher (1987) 'The Concept of War in Modern International Law', International and Comparative Law Quarterly, 36:2, 283-306

Grob, Fritz (1949) The Relativity of War and Peace: A Study in Law, History and Politics ([S.1.]: Yale University Press)

Grotius, Hugo (1625) De Jure Belli ac Pacis Libri Tres (translated by Francis W. Kelsey; Oxford: Clarendon Press, 1925)

Habibi, Roojin and Steven J Hoffman (2018) 'Legalizing Cannabis Violates the UN Drug Control Treaties, but Progressive Countries Like Canada Have Options', Ottawa Law Review, 49:2, $427-460$

Hakimi, Monica (2017) ‘The Work of International Law', Harvard International Law Journal, 58:1, 146

Hakimi, Monica (2018) 'The Jus ad Bellum's Regulatory Form', American Journal of International Law, 112:2, 151-190

Henckaerts, Jean-Marie and Louise Doswald-Beck (eds) (2005) Customary International Humanitarian Law, Volume I: Rules (Cambridge: Cambridge University Press)

Henkin, Louis (1979) How Nations Behave: Law and Foreign Policy (New York: Columbia University Press, 2nd)

Higgins, Rosalyn (1994) Problems and Process: International Law and How We Use It (Oxford: Clarendon Press)

Hill, Steven (2016) 'The Role of NATO's Legal Adviser', in Zidar, Andraž and Jean-Pierre Gauci (eds), The Role of Legal Advisers in International Law (Leiden: Martinus Nijhoff), 213-236

Hoffman, Frank G (2007) Conflict in the 21st Century: The Rise of Hybrid Warfare (Arlington: Potomac Institute for Policy Studies)

Hoffman, Frank G (2009) 'Hybrid Warfare and Challenges', Joint Force Quarterly, 52:1, 34-39

Holling, C S (1973) 'Resilience and Stability of Ecological Systems', Annual Review of Ecology and Systematics, 4, 1-23

Horton, Scott (2010) 'The Dangers of Lawfare', Case Western Reserve Journal of International Law, 43, 163-179

Hughes, David (2016) 'What Does Lawfare Mean?', Fordham International Law Journal, 40:1, 1-40

Humby, Tracy-Lynn (2014) 'Law and Resilience: Mapping the Literature', Seattle Journal of Environmental Law, 4:1, 85-130

Hurd, Ian (2017) How to Do Things with International Law (Princeton: Princeton University Press)

International Security Advisory Board (2017) Report on Gray Zone Conflict (Washington DC: United States State Department) 
Irani, Freya (2017) 'Lawfare', US Military Discourse, and the Colonial Constitution of Law and War', European Journal of International Security, 3:1, 113-133

Jackson, Van (2017) 'Tactics of Strategic Competition: Gray Zones, Redlines, and Conflicts before War', Naval War College Review, 70:3, 39-62

Joint Chief of Staff (2019) Joint Doctrine Note 1-19: Competition Continuum (Washington, DC:

Kennedy, David (2006) Of W ar and Law (Princeton: Princeton University Press)

Kerr, Rachel (2004) The International Criminal Tribunal for the Former Yugoslavia: An Exercise in Law, Politics, and Diplomacy (Oxford: Oxford University Press)

Kittrie, Orde F (2016) Lanfare: Law as a Weapon of War (Oxford: Oxford University Press)

Korman, Sharon (1996) The Right of Conquest: The Acquisition of Territory by Force in International Law and Practice (Oxford: Clarendon)

Koskenniemi, Martti (1990) 'The Politics of International Law', European Journal of International Law, $1: 1,4-32$

Koskenniemi, Martti (2005) From Apology to Utopia: The Structure of International Legal Argument (Cambridge: Cambridge University Press, 2nd)

Koskenniemi, Martti (2009) 'The Politics of International Law-20 Years Later', European Journal of International Law, 20:1, 7-19

Kraska, James (2018) 'The Kerch Strait Incident: Law of the Sea or Law of Naval Warfare?', EJIL:Talk, < https://www.ejiltalk.org/the-kerch-strait-incident-law-of-the-sea-or-law-ofnaval-warfare/>

Kunz, Josef L. (1945) 'The Problem of the Progressive Development of International Law', Iowa Law Review, 31:4, 544-560

Lauterpacht, Hersch (1933) The Function of Law in the International Community (Oxford: Clarendon)

Leed, Maren (2015) 'Square Pegs, Round Holes, and Gray Zone Conflicts', Georgetown Journal of International Affairs, 16:2, 133-143

Luban, David (2010) 'Carl Schmitt and the Critique of Lawfare', Case Western Reserve Journal of International Law, 43, 457-471

Luhmann, Niklas (2004) Law as a Social System (Oxford: Oxford University Press)

Mälksoo, Maria (2018) 'Countering Hybrid Warfare as Ontological Security Management: The Emerging Practices of the EU and NATO', European Security, 27:3, 374-392

Mattis, James N and Frank G Hoffman (2005) 'Future Warfare: The Rise of Hybrid Wars', Proceedings Magazine, Issue 131, 18-19

Maurice, John Frederick (1883) Hostilities without Declaration of War (London: HMSO)

Mazarr, Michael J (2015) Mastering the Gray Zone: Understanding a Changing Era of Conflict (Carlisle: Strategic Studies Institute and US Army War College)

Mazarr, Michael J., Jonathan Blake, Abigail Casey, Tim McDonald, Stephanie Pezard and Michael Spirtas (2018) Understanding the Emerging Era of International Competition: Theoretical and Historical Perspectives (Santa Monica: RAND)

Mearsheimer, John J (1994) 'The False Promise of International Institutions', International Security, 19:3, 5-49

Ministry of Defence (2019) Joint Doctrine Publication 3-46: Legal Support to Joint Operations (London: Ministry of Defence)

Ministry of Foreign Affairs of China (2016) 'Statement of the Ministry of Foreign Affairs of the People's Republic of China on the Award of 12 July 2016 of the Arbitral Tribunal in the South China Sea Arbitration Established at the Request of the Republic of the Philippines', Chinese Journal of International Law, 15:4, 905-907

Monaghan, Andrew (2015) 'The "War" in Russia's "Hybrid Warfare", Parameters, 45:4, 65-74

Morgenthau, Hans Joachim (1929) Die internationale Rechtspflege, ibr Wesen und ibre Grenzen (Leipzig: Noske)

Morgenthau, Hans Joachim (1948) Politics Among Nations: The Struggle for Power and Peace (New York: Knopf) 
Morton, Jeffrey S. (2002) 'The Legality of NATO's Intervention in Yugoslavia in 1999: Implications for the Progressive Development of International Law', ILSA Journal of International and Comparative Law, 9:1, 75-102

Multinational Capability Development Campaign (2019) MCDC Countering Hybrid Warfare Project: Countering Hybrid Warfare (London: Ministry of Defence)

Muñoz Mosquera, Andres B and Sascha Dov Bachmann (2016) 'Lawfare in Hybrid Wars: The 21st Century Warfare', Journal of International Humanitarian Legal Studies, 7:1, 63-87

Nasu, Hitoshi (2016) 'Japan's 2015 Security Legislation: Challenges to Its Implementation under International Law', International Law Studies, 92, 248-280

Neff, Stephen C. (2005) War and the Law of Nations: A General History (Cambridge: Cambridge University Press)

Noone, Gregory P. (2010) 'Lawfare or Strategic Communications?', Case Western Reserve Journal of International Law, 43:1-2, 73-86

O'Connell, Mary Ellen (2015) 'Myths of Hybrid Warfare', Ethics and Armed Forces, 2:2, 27-30

Olson, Peter M. (2014) 'The Lawfulness of Russian Use of Force in Crimea', Military Law and the Law of War Review, 53:1, 17-44

Patrikarakos, David (2017) War in 140 Characters: How Social Media is Reshaping Conflict in the Twentyfirst Century (New York: Basic Books)

Peters, Anne (2018) 'How Not to Do Things with International Law', Ethics and International Affairs, $32: 4,483-491$

Plokhy, Serhii (2011) 'The Call of Blood: Government Propaganda and Public Response to the Soviet Entry into World War II', Cabiers du Monde russe, 52:2/3, 293-319

Porter, Patrick (2016) 'Sorry, Folks. There Is No Rules-Based World Order', National Interest, $<$ http://nationalinterest.org/blog/the-skeptics/sorry-folks-there-no-rules-based-worldorder-17497>

Porter, Patrick (2018) A World Imagined: Nostalgia and Liberal Order, Policy Analysis No 843 (Washington, DC: CATO Institute), <https://www.cato.org/publications/policyanalysis/world-imagined-nostalgia-liberal-order $>$

Porter, Patrick (2019) 'Advice for a Dark Age: Managing Great Power Competition', The W ashington Quarterly, 42:1, 7-25

Reisman, W Michael (1998) 'Stopping Wars and Making Peace: Reflections on the Ideology and Practice of Conflict Termination in Contemporary World Politics', Tulane Journal of International and Comparative Law, 6:1, 5-56

Reisman, W Michael (2013) The Quest for World Order and Human Dignity in the Twenty-First Century: Constitutive Process and Individual Commitment (The Hague: Hague Academy of International Law)

Renz, Bettina (2016) 'Russia and "Hybrid Warfare", Contemporary Politics, 22:3, 283-300

Rich, Roland (1993) 'Recognition of States: The Collapse of Yugoslavia and the Soviet Union', European Journal of International Law, 4:1, 36-65

Roberts, Anthea (2017) Is International Law International? (Oxford: Oxford University Press)

Rowe, Peter (2016) Legal Accountability and Britain's Wars 2000-2015 (Abingdon: Routledge)

Ruggie, John Gerard (1993) 'Wandering in the Void: Charting the UN's New Strategic Role', Foreign Affairs, 72:5, 26-31

Ruhl, J B (2010) 'General Design Principles for Resilience and Adaptive Capacity in Legal Systems-With Applications to Climate Change Adaptation Adaptation and Resiliency in Legal Systems', North Carolina Law Review, 89:5, 1373-1404

Sari, Aurel (2019) 'Hybrid Warfare, Law and the Fulda Gap', in Christopher M. Ford and Winston S. Williams (eds), Complex Battlespaces: The Law of Armed Conflict and the Dynamics of Modern Warfare (Oxford: Oxford University Press), 161-190

Schachter, Oscar (1982) 'International Law in Theory and Practice: General Course in Public International Law', Recueil des Cours, 178-V, 1-395 
Schelling, Thomas C. (2008) Arms and Influence (New Haven: Yale University Press)

Schmitt, Michael N and Andru E Wall (2014) 'The International Law of Unconventional Statecraft', Harvard National Security Journal, 5:2, 349-376

Schwarzenberger, Georg (1943) 'Jus Pacis Ac Belli?: Prolegomena to a Sociology of International Law', American Journal of International Law, 37:3, 460-479

Shany, Yuval (2014) 'Does International Law Grant the People of Crimea and Donetsk a Right to Secede: Revisiting Self-Determination in Light of the 2014 Events in Ukraine', Brown Journal of W orld Affairs, 21:1, 233-244

Shea, Jamie (2016) 'Resilience: A Core Element of Collective Defence', NATO Review, $<$ https://www.nato.int/docu/review/2016/also-in-2016/nato-defence-cyberresilience/en/index.htm>

Simpson, Gerry (2001) 'Two Liberalisms', European Journal of International Law, 12:3, 537-572

Ssenyonjo, Manisuli (2018) 'State Withdrawal Notifications from the Rome Statute of the International Criminal Court: South Africa, Burundi and the Gambia', Criminal Law Forum, 29:1, 63-119

Stephens, Dale (2011) 'The Age of Lawfare', International Law Studies, 87, 327-357

Talmon, Stefan (2019) 'The United States under President Trump: Gravedigger of International Law', Chinese Journal of International Law, 18:3, 645-668

Tamanaha, Brian Z. (2006) Law as a Means to an End: Threat to The Rule of Law (Cambridge: Cambridge University Press)

Tenenbaum, Élie (2015) 'Hybrid Warfare in the Strategic Spectrum: An Historical Assessment', in Guillaume Lasconjarias and Jeffrey A Larsen (eds), NATO's Response to Hybird Threats (Rome: NATO Defense College), 95-112

Thucydides (2009) The Peloponnesian War (translated by Hammond, Martin; Oxford: Oxford University Press)

Trachtman, Joel P. (2016) 'Integrating Lawfare and Warfare', Boston College International and Comparative Law Review, 39:2, 267-282

Tugendhat, Tom and Laura Croft (2013) The Fog of Law: An Introduction to the Legal Erosion of British Fighting Power (London: Policy Exchange)

United States Department of State (1956) Foreign Relations of the United States: Diplomatic Papers, 1939, Vol I (Washington, D.C.: U.S. Government Printing Office)

United States Special Forces Command (2015) The Gray Zone (Tampa, Florida: United States Special Forces Command)

Voetelink, Joop (2017) 'Reframing Lawfare', in Ducheine, Paul A.L. and Frans P.B. Osinga (eds), Netherlands Annual Review of Military Studies (Winning Without Killing: The Strategic and Operational Utility of Non-Kinetic Capabilities in Crises) (The Hague: TMC Asser), 237-254

Wassermann, Felix Martin (1947) 'The Melian Dialogue', Transactions and Proceedings of the American Philological Association, 78, 18-36

Wirtz, James J. (2017) 'Life in the "Gray Zone": Observations for Contemporary Strategists', Defense and Security Analysis, 33:2, 106-114

Wittes, Benjamin (2015) 'What Is Hybrid Conflict?', Lawfare, <https://lawfareblog.com/whathybrid-conflict>

Wright, Jeremy (2018) 'Cyber and International Law in the 21st Century', $<$ https://www.gov.uk/government/speeches/cyber-and-international-law-in-the-21st-

century $>$ 